\title{
Politics of the mind: Marxism and mental distress
}

\author{
lain Ferguson \\ Bookmarks Publications, 2017. \\ ISBN 978-1-910885-65-9, pp. 149, paperback, NZD19.73
}

$\mathrm{L}$ ike the author of this text, I was very influenced by the work of the Scottish anti-psychiatrist R.D. Laing during the seventies. In fact, although it was by a very circuitous route, reading the work of Ronnie Laing was one of the reasons I eventually became a social worker. Nowadays, I look back on the iconoclastic ideas of the anti-psychiatrists, as they became known, with a critical eye, but still recognise the value of their challenge to the psychiatric establishment. In this little gem of a text, which belongs on the bookshelf of every social worker, Iain Ferguson offers another challenge to mainstream psychiatry and the dominance of the biomedical model, but this time from a Marxist and materialist perspective.

The first chapter sets the scene and the context of the crisis in mental health facing the populations of all developed countries. According to the World Health Organisation, mental health conditions are on the rise globally: depression, for example, affects over 300 million people worldwide, and has become the single leading cause of disability in the world (WHO, 2018). In the opening chapter Ferguson explains why he chooses to use the term mental distress as a more neutral term than mental illness, a term that is less stigmatising and better captures the multidimensional nature of the phenomena. Mental distress is common in Aotearoa New Zealand with about four in five adults (aged 15 years or more) having experienced it personally or knowing someone who has (Kvalsvig, 2018). Although anyone can experience mental distress, in Aotearoa New Zealand, it is strongly associated with being young, deprived or Māori and with feelings of isolation (Kvalsvig, 2018).

Ferguson highlights the relationship between unemployment, beneficiary status and the intensification of work processes under neoliberalism as a key correlate of mental distress. These points resonate strongly with the New Zealand data where the highest levels of life satisfaction are reported by the retired population and the lowest amongst beneficiaries, people looking for work and students (Kvalsvig, 2018). Ferguson states that the central argument of his text is that "it is the economic and political system under which we live-capitalism-that is responsible for the enormously high levels of mental health problems which we see in the world today" (p.15). He argues in favour of a Marxist analysis that is materialist (recognises the material facts of experience), historical (acknowledges the impact of current political and social forces) and dialectical (rejects reductionism in favour of an approach that traces the interaction between material circumstances and human agency).

In the chapters that follow Ferguson develops his argument with clarity and rigour. Chapter two, All in the Brain, summarises the history and hegemony of brain-based psychiatry from models of madness in antiquity, to the history of the asylum, to the current dominance of the Diagnostic and Statistical Manual of Mental Disorders (produced by the American Psychiatric Association) which has, as Ferguson argues, "contributed to the medicalisation of human nature and everyday life" (p.43). The following chapter 
on Marxism and Psychoanalysis gives a wellrounded assessment of the contribution of psychoanalysis to our understanding of mental distress contrasting the conservative views of conventional Freudians on sexuality with the feminist psychoanalytic perspectives of Juliet Mitchel and others. Included in the scope of this chapter is a fascinating aside on the positive attitudes towards psychoanalytic thought held by members of the Bolshevik party in the early years of the Soviet Union and a section introducing some key ideas from the "notoriously difficult" (p. 69) French psychoanalyst Jacque Lacan.

Chapter four addresses the anti-psychiatry movement of the 1960's and 1970s associated with the work of R.D. Laing, David Cooper and Thomas Szasz, outlining the similarities and differences in thinking between these anti-psychiatrists and how their arguments developed over time. Ferguson's assessment of R.D. Laing is particularly well-informed, finely nuanced and compelling (see also Ferguson's classic book review of The Divided Self elsewhere in this issue). The penultimate chapter on New Challenges to the Psychiatric Hegemony offers an assessment of contemporary alternatives to the prevailing biomedical model including trauma studies, dissociation, attachment theory and the mental health service user movement. In this chapter Ferguson critiques the arguments of the University of Auckland sociologist Bruce Cohen (Cohen, 2016) who argues that a Marxist analysis of the hegemony of psychiatry leads inevitably to a recommendation for the wholesale abolition of psychiatric services, a perspective that has an odd alignment with the views of the Church of Scientology (McAllan, 2021). As Ferguson asserts, arguments for the abolition of psychiatric services that are already under significant material duress would be, "music to the ears of right-wing politicians" (p.116) and bring nothing but misery to people experiencing mental distress and their families. Rather than abolishing psychiatric services, Ferguson argues for a radical, humane, social and dialectical approach:

A model for mental distress which recognises-and provides empirical evidence for-the causal role played by early life experience, poverty, inequality, racism, sexism and other forms of oppression in the genesis of mental health problems is a huge step forward from a model which locates such problems primarily in faulty genes or biochemical deficiencies. The fact also that the new paradigm does not discount genes, brains and biochemistry but rather emphasises the interaction between our brains and our environments...allows for a much more dialectical understanding of mental distress (p. 104).

In the final chapter Taking control: Alienation and Mental Health Ferguson contrasts the views of human nature espoused by Freud and Marx with the former highlighting the struggle of the ego to repress the unruly needs of the id, and the latter emphasising the compelling need for humans to produce the means of subsistence by transforming the world through labour. Ferguson argues, from a Marxist perspective, that what makes us truly human is the ability to consciously control our own labour. And yet, it is precisely this aspect of our humanity that is most suppressed by an economic system founded on class division, competition and ruthless individualism. The key Marxist concept for thinking about mental distress, Ferguson argues, is alienation: alienation from the products of our labour, alienation from the labour process and alienation from each other. The real value of the Marxist concept of alienation is that it helps to trace the impact of capitalism on social relations and on individual consciousness. The societal impact of four decades of neoliberalism has not only deepened economic inequality, it has induced profound sense of powerlessness, 
disconnection and precarity. Ferguson argues that we need more than a revolution in mental health services, to counter these conditions, and concludes that:

...the priority for all of us who wish to improve our own mental health and the mental health of those around us is both to participate in collective struggles for more and better mental health services-to support the shift back from "worry lines to picket lines"-and also to fight for a world where such services are no longer required (p. 134).

\section{References}

Cohen, B. M. Z. (2016). Psychiatric hegemony: A Marxist theory of mental Illness. Palgrave Macmillan.

Kvalsvig, A. (2018). Wellbeing and mental distress in Aotearoa New Zealand: Snapshot 2016. Health Promotion Agency. https://www.hpa.org.nz/ research-library/research-publications/wellbeingand-mental-distress-in-aotearoa-new-zealandsnapshot-2016

McAllan, J. (2021, July). The anti-depressant syndicate: The friends and foes of big anti-pharma. The Baffler. https://thebaffler.com/salvos/the-anti-antidepressantsyndicate-mcallen

World Health Organisation (2018). Depression. http://www.who.int/news-room/fact-sheets/detail/ depression

Reviewed by Neil Ballantyne, Senior Lecturer in Social Work, Open Polytechnic of New Zealand 